\title{
PENGARUH KOMPETENSI SUMBER DAYA MANUSIA, SISTEM PENGENDALIAN INTERN PEMERINTAH DAN PENERAPAN SISTEM AKUNTANSI KEUANGAN DAERAH TERHADAP KUALITAS LAPORAN KEUANGAN PEMERINTAH PROVINSI PAPUA
}

\author{
ABSTRACT \\ Erwin Siahaya ${ }^{1}$ \\ jurnalmkd@gmail.com \\ Meinarni Asnawi ${ }^{2}$ \\ meinarni.asnawi@gmail.com \\ Paulus K. Allo Layuk ${ }^{3}$ \\ paskal967@gmail.com
}

The purpose of this study is to examine and analyze the influence of competence of human resources, government internal control system and the application of regional financial accounting system to the quality of local financial statements. The population is a financial administration staff of 49 SKPD, while the sample amounted to 120 . Data collection was done by direct survey. Hypothesis testing is empirically tested using Multiple Regression.

The results of partial research on the quality of human resources have a positive effect on the quality of financial statements. The government's internal control system has a positive effect on the quality of local government financial reports. Other findings of the local government accounting system have a positive effect on the quality of local government financial reports. While the results simultaneously have a positive and significant effect on the quality of the Government's financial statements.

Keywords: Human Resources Competency, Government Internal Control System, Application of Local Financial Accounting System and Quality of Regional Financial Report.

\section{PENDAHULUAN}

Laporan Keuangan Kementerian Lembaga (LKKL) dan Laporan

Keuangan Pemerintah Daerah (LKPD) menjadi isu yang santer di kalangan

Bupati, Walikota, Gubernur, dan Menteri bahkan sampai Presiden. Ini semua

\footnotetext{
${ }^{1}$ Alumni Mahasiswa Magister Keuangan Daerah Universitas Cenderawasih

2 Staf Dosen Jurusan IImu Akuntansi Fakultas Ekonomi \& Bisnis Universitas Cenderawasih

${ }^{3}$ Staf Dosen Jurusan IImu Akuntansi Fakultas Ekonomi \& Bisnis Universitas Cenderawasih
} 
terkait dengan target pemerintah, bahwa pada tahun 2015 opini WTP harus mencapai $60 \%$.

Permasalahan yang menghambat belum diperolehnya opini WTP beragam. Khusus terhadap LKPD, masih terkait dengan pengelolaan kas, persediaan, investasi permanen dan nonpermanen, serta secara mayoritas disebabkan karena pengelolaan aset tetap yang belum akuntabel (sumber: http://www.bpkp.go.id/).

Suwardjono (2005) menyatakan bahwa tujuan utama dalam pelaporan keuangan organisasi non bisnis seperti unit-unit kepemerintahan yaitu untuk menyediakan informasi yang bermanfaat bagi para penyedia dana dan pemakai lain, baik berjalan maupun potensial, dalam membuat keputusankeputusan rasional tentang alokasi dana ke organisasi tersebut.

Realita yang terjadi menurut situmorang (2016) selaku Kepala Inspektorat Provinsi Papua bahwa pemahaman SKPD terhadap kebijakan akuntabilitas berbasis akrual belum dipahami dengan baik, karena masing" SKPD belum ada yang focus memahami masalah akuntansi misalnya jurusan akuntansi, banyak yang belum memahami masalah keuangan. Sehingga masih sulit untuk diterapkan (www.beritapapua.dharapos.com)

Untuk menghasilkan laporan keuangan daerah yang berkualitas dan dapat berjalan efektif tentunya diperlukan sumber daya manusia yang memahami dan kompeten dalam akuntansi pemerintahan, keuangan daerah yang berkualitas guna menunjang kualitas Laporan Keuangan Pemerintah Daerah (LKPD).

Hal yang perlu diperhatikan adalah kompetensi aparatur pemerintah daerah yang terlibat dalam penyusunan laporan keuangan. Realita yang terjadi selama ini masih terbatasnya pegawai yang berlatar belakang pendidikan bidang akuntansi menjadikan kurangnya pemahaman atau penguasaan aparatur Satuan Kerja Perangkat Daerah dalam mengelola keuangan daerah dengan baik dan benar.

Pernyataan di atas sejalan dengan kajian yang dilakukan oleh Andini dan Yusrawati (2014) dengan judul kajian pengaruh kompetensi sumber 
daya manusia dan penerapan sistem akuntansi keuangan daerah terhadap kualitas laporan keuangan daerah Pada Satuan Kerja Perangkat Daera (SKPD) Kabupaten Empat Lawang Sumatera Selatan. Hasil kajian menemukan secara parsial variabel kompetensi SDM berpengaruh terhadap kualitas laporan keuangan daerah.

Hasil kajian ini di dukung dengan kajian Wati dkk (2014) dengan judul kajian pengaruh kompetensi SDM, penerapan SAP, dan sistem akuntansi keuangan daerah. Hasil kajian menemukan kompetensi sumber daya manusia berpengaruh positif dan signifikan terhadap kualitas laporan keuangan daerah.

Namun kedua hasil kajian diatas kontradiktif (bertolak belakang) dengan kajian yang dilakukan Syarifudin (2014) dengan judul kajian pengaruh kompetensi sdm dan peran audit intern terhadap kualitas laporan keuangan pemerintah daerah dengan variabel intervening sistem pengendalian internal pemerintah (studi empiris pada Pemkab Kebumen).

Secara umum kompetensi sumber daya manusia tidak memberikan dorongan yang kuat kualitas LKPD, yang secara umum memiliki makna yaitu meningkatnya variable kompetensi tidak memiliki pengaruh terhadap peningkatan kualitas (LKPD).

Selain faktor kompetensi SDM, faktor yang mampu mempengaruhi kulaitas laporan kuengan daerah adalah sistem pengendalian intern pemerintah dan sistem informasi akuntansi keuangan daerah. Dalam PP No. 60 Tahun 2008, mendefinisikan sistem pengendalian intern adalah proses yang integral pada tindakan dan kegiatan uang dilakukan terus-menerus oleh pimpinan dan seluruh pegawai untuk memberikan keyakinan yang memadai atas kegiatan yang efektif dan efisien.

Faktor terakhir yang dapat mempengaruhi kualitas laporan keuangan pemerintah daerah selain SPIP yaitu penerapan sistem informasi akuntansi keuangan daerah. SAKD merupakan suatu proses pengidentifikasian, pengukuran, pencatatan, dan pelaporan transaksi ekonomi (keuangan) dari entitas pemda yang di-jadikan sebagai informasi dalam rangka pengambilan 
keputusan ekonomi yang diperlukan oleh pihak-pihak eksternal entitas pemda yang disusun berdasarkan Standar Akuntansi Pemerintah (Mahsun, 2006). Selanjutnya Peraturan Pemerintah RI No. 56 Tahun 2005, mendefinisikan Sistem Informasi Keuangan Daerah selanjutnya disingkat SIKD adalah "Suatu sistem yang mendokumentasikan, mengadministrasikan, serta mengolah data pengelolaan keuangan daerah dan data terkait lainnya menjadi informasi yang disediakan kepada masyarakat serta juga dipakai sebagai bahan pengambilan keputusan dengan memegang pada unsur perencanaan, pelaksanaan dan pelaporan pertanggungjawab pemerintah daerah.

Pernyataan diatas sejalan dengan kajian yang dilakukan oleh Andini dan Yusrawati (2015) dimana hasil kajian menunjukan penerapan sistem akuntansi keuangan daerah berpengaruh terhadap kualitas laporan keuangan daerah. Hasil kajian ini terdukungn dengan kajian yang dilakukan oleh Wati dkk (2014) menumukan bahwa sistem akuntansi keuangan daerah berpengaruh positif dan signifikan terhadap kualitas laporan keuangan daerah.

Hasil kajian-kajian empiris, fenomena dan realita diatas ternyata menunjukan adanya ambivalensi hasil penelitian. Artinya ambivalensi atau kontradiksi hasil penelitian tersebut sebenarnya adalah research gap (kesenjangan penelitian) yang oleh Agusty, (2006) disebutkan bahwa research gap tersebut dapat atau seharusnya dikembangkan sebagai masalah penelitian yang perlu diinventigasi lebih lanjut.

Berdasarkan pertimbangan inilah maka tujuan dalam penelitian ini adalah sebagai berikut: (1) Untuk menguji dan menganlisis pengaruh kompetensi sumber daya manusia terhadap kualitas laporan keuangan Pemerintah Daerah Provinsi Papua; (2) Untuk menguji dan menganalisis pengaruh sistem pengendalian intern terhadap kualitas laporan keuangan Pemerintah Daerah Provinsi Papua.

Jensen dan Meckling, 1976 menjelaskan bahwa Teori keagenan dapat didefinisikan sebagai suatu hubungan yang terdapat pada suatu kontrak 
dimana satu orang atau lebih (principal) memerintah orang lain (agen) untuk melakukan suatu jasa atas nama prinsipal dan memberi wewenang kepada agen untuk membuat keputusan yang terbaik bagi principal.

Halim dan Abulah, (2005) menyatakan bahwa pelaksanaan otonomi daerah merupakan pelimpahan wewenang dari pemerintah kepada kepala daerah menunjukan adanya hubungan keagenan .

Good corporate governance (GCG) secara definitif merupakan sistem yang mengatur dan mengendalikan perusahaan yang menciptakan nilai tambah (value added) untuk semua stakeholder (Monks,2003). Konsep ini menekankan pada dua aspek, pertama pentingnya pemegang saham memperoleh informasi dengan benar dan tepat pada waktunya dan kedua kewajiban perubahan melakukan pengungkapan secara akurat, tepat waktu, transparansi terhadap semua informasi tentang kinerja perusahaan, kepemilikan dan stakeholder.

Susilo dan Simamarta (2007:15-16) mengatakan bahwa corporate governance mempunyai dua aspek, yaitu: Aspek pertama, berkaitan dengan pola hubungan dan perilaku para aktor dalam perseroan. Perilaku manajemen dengan karyawan, perilaku perseroan dengan pemasok, dengan kreditor, dan lain-lain. Ukurang yang dipakai untuk melihat perilaku yang memberikan manfaat melalui tingkat efisiensi perusahaan.

Paton (Suwardjono, 2005) dalam teorinya, bahwa organisasi dianggap sebagai suatu kesatuan atau badan usaha ekonomik yang berdiri sendiri, bertindak atas nama sendiri, dan kedudukannya terpisah dari pemilik atau pihak lain disyaratkan oleh pekerjaan dalam suatu organisasi sehingga organisasi tersebut mampu mencapai hasil yang diharapkan".

Sesuai pasal 58 (1) UU No. 1 Tahun 2004, bahwa Presiden menyelenggarakan Sistem Pengendalian Internal Pemerintah (SPIP) dalam rangka pengelolaan keuangan negara. Sistem pengendalian internal adalah proses yang integral pada tindakan dan kegiatan yang dilakukan secara terus menerus oleh pimpinan dan seluruh pegawai untuk memberikan keyakinan memadai atas tercapainya tujuan organisasi melalui kegiatan 
yang efektif dan efisien, keandalan pelaporan keuangan, pengamanan aset negara, dan ketaatan terhadap peraturan perundangundangan (PP No. 60 tahun 2008).

Menurut Midjan dan Susanto (2001) menyatakan bahwa: "Sistem informasi akuntansi merupakan suatu sistem pengolaan data akuntansi yang merupakan koordinasi dari manusia, alat dan metode yang berinteraksi secara harmonis dalam suatu wadah organisasi yang terstruktur untuk menghasilkan informasi akuntansi keuangan dan informasi akuntansi manajemen yang berstruktur pula".

Sedangkan menurut Mahmudi (2007:11) definisi laporan keuangan adalah: "Laporan keuangan adalah informasi yang disajikan untuk membantu stakeholder dalam membuat keputusan sosial, politik dan ekonomi sehingga keputusan yang diambil bisa lebih berkualitas."

Menurut Halim (2012:43) "Akuntansi kauangan daerah adalah proses penidentifikasian, pengukuran, pencatatan, dan pelaporan transaksi ekonomi (keuangan) dari entitas pemerintah daerah (Kabupaten, Kota atau Provinsi) yang memerlukan".

Dalam memiliki keinginan pemakai laporan, akuntansi keuangan perlu berupaya untuk membentuk dirinya agar lebih bermanfaat dan berdaya guna. Oleh karena itu perlu kriteria persyaratan laporan akuntansi keuangan yang dianggap dapat memenuhi keinginan tersebut yaitu keinginan para pemakai laporan keuangan (Harahap, 2008;145).

Karakteristik kualitatif laporan keuangan menurut Peraturan Pemerintah Nomor 71 tahun 2010 tentang standar akuntansi pemerintah (SAP) adalah sebagai berikut: "kualitas pelaporan keuangan pada umumnya menjelaskan unsur-unsur normative yang membutuhkan informasi akuntansi sehingga dapat memenuhi tujuannya".

\section{METODE PENELITIAN}

Teknik analisis dalam penelitian ini terdiri dari analisis deskriptif dan analisis statistik. Kedua teknik ini digunakan untuk mendapatkan hasil yang optimal. 
Sementara data yang dikumpulkan meliputi data primer dan data sekunder yang diperoleh melalui tehnik wawancara, penyebaran kuisioner dan kepustakaan.

\section{HASIL DAN PEMBAHASAN}

Pengaruh Kompetensi SDM (KSDM) Terhadap Kualitas Laporan Keuangan Pemerintah Daerah (KLKPD) Provinsi Papua. Hasil analisis pada Tabel 4.9 membuktikan bahwa Kompetensi SDM (KSDM) berpengaruh positif dan signifikan terhadap Kualitas Laporan Keuangan Pemerintah Daerah (KLKPD) Provinsi Papua. Hal ini dapat dibuktikan melalui koefisien regresi yang menunjukan jika KSDM meningkat, maka peningkatan tersebut akan diikuti oleh peningkatan KLKPD Provinsi Papua.

Berdasarkan hasil wawancara yang penulis lakukkan terhadap Kepala Inspektorat Provinsi Papua Anggiat Situmorang dimana dijelaskan bahwa kompetensi sumber daya yang dimiliki inspektorat sendiri masih sangat rendah, hal ini di tunjukan dengan rekrutmen awal yang dilakukan di lingkungan Pemerintah Provinsi Papua.

Tidak memperhatikan latarbelakang pendidikan dari pegawai tersebut sehingga dalam penempatan pegawai pada Inspektorat sendiri tidak menempatkan pegawai dengan latar belakang pendidikan akuntansi yang seharusnya di tempatkan pada Inspektorat Provinsi Papua namun sebaliknya menempatkan pegawai yang bukan berlatarbelakang akuntansi lebih dominan dari pegawai yang berlatarbelakang pendidikan akuntansi sehingga dalam menjalankan fungsi dan peran Inspektorat sendiri, belum mampu menjalankan fungsi dan peran dangan baik.

Upaya yang telah dilakukan sebagai komitmen pimpinan Inspektorat Provinsi Papua dalam mengatasi kompetensi sumber daya manusia yang dimiliki dengan melakukan pelatihan dan bimbingan teknis (Bimtek) dengan bekerjasama dengan BPKP Provinsi Papua dan Ikatan Akuntan Indonesia (IAI) dalam memberikan pelatihan tentang tata kelola keuangan dan audit berbasis resiko kepada para pegawai dengan 
harapan upaya yang telah dilakukan dapat meningkatkan kompetensi pegawai sekaligus dapat meningkatkan peran dan fungsi Inspektorat dapat berjalan secara maksimal.

Hasil temuan diatas menunjukan bahwa kompetensi sumber daya manusia memiliki nilai $t$ hitung yang lebih kecil dibandingkan dengan SPIP dan SAKD hal ini disebabkan karena penempatan pegawai sebagai bendahara maupun kepala sub bagian keuangan di lingkungan pemerintah Provinsi Papua tidak berdasarkan pada kemampuan atau kompetensi yang dimiliki oleh pegawai (the right man in the right places) artinya penenmpatan pegawai tidak berdasarkan kemampuan dan kompetensi yang dimiliki namun penempatan orang berdasarkan pada kepentingan politik semata.

Sehingga pegawai yang menduduki jabatan baik bendahara maupun kepala sub bagian akuntansi yang menduduki jabatan tersebut belum memahami secara benar filosofi akuntansi yang seharusnya diterapakan.

Realita yang terjadi di lingkungan Pemerintah Provinsi Papua sejalan dengan hasil temuan dalam penelitian ini hal ini bias ditunjukan dengan nilai t hitung kompetensi sumber daya manusia sebesar 2,996 lebih kecil dibandingkan dengan nilai t hitung SPIP dan penerapan SAKD.

Temuan ini sejalan dengan pendapat Wahyono, (2004) bahwa setiap bagian dalam pemerintahan harus diisi oleh orang yang tepat, yaitu yang memiliki kompetensi yang sesuai dengan Tupoksi (Tugas Pokok dan Fungsi) yang telah ditentukan. Begitupun bagian keuangan yang harus disi oleh sumber daya manusia yang memiiki kompetensi akuntansi dan ilmuilmu keuangan terkait lainnya.

Hal inilah yang mendorong instansi pemerintah untuk terus berkembang dan meningkatkan kompetensi yang dimiliki melalui pelatihan yang diselenggarakan dan kebijakan lainnya yang mendukung pencapaian tujuan.

Temuan ini juga diperkuat oleh Dewi Andini dan Yusrawati, (2015) yang juga menyatakan bahwa adanya keterbatasan Sumber Daya Manusia (SDM) yang memahami mekanisme penyusunan laporan keuangan yang 
sesuai dengan Standar Akuntansi Pemerintahan menjadi kendala dalam mewujudkan LKPD yang berkualitas. Dengan demikian dapat dikatakan bahwa peningkatan KSDM akan meningkatkan KLKPD Provinsi Papua.

Hasil temuan kajian ini sejalan dengan kajian Wati dkk., (2014) dengan judul kajian pengaruh kompetensi SDM, penerapan SAP dan sistem akuntansi keuangan daerah. Hasil kajian menemukan kompetensi sumber daya manusia berpengaruh positif dan signifikan terhadap kualitas laporan keuangan daerah.

Namun hasil kajian ini kontradiktif (bertolak belakang) dengan kajian yang dilakukan Syarifudin, (2014) dengan judul kajian pengaruh kompetensi SDM dan peran audit intern terhadap kualitas laporan keuangan pemerintah daerah dengan variabel intervening sistem pengendalian internal pemerintah (studi empiris pada Pemkab Kebumen).

Hasil penelitian menunjukan kompetensi SDM tidak berpengaruh signifikan terhadap kualitas LKPD, artinya meningkatnya variasi kompetensi tidak berpengaruh signifikan terhadap peningkatan kualitas LKPD.

Pengaruh Sistim Pengendalian Internal Pemerintah (SPIP) Terhadap Kualitas Laporan Keuangan Pemerintah Daerah (KLKPD) Provinsi Papua. Hipotesis kedua menyatakan bahwa "Sistem Pengendalian Intern Pemerintah (SPIP) berpengaruh terhadap Kualitas Laporan Keuangan Pemerintah Daerah (KLKPD) Provinsi Papua". Berdasarkan hasil analisis diketahui bahwa nilai t hitung koefisien SPIP sebesar 5.283 yang adalah lebih besar dari t tabel sebesar $1.979(5.283$ > 1.979) dengan signifikansi 0.000 yang juga lebih kecil dari nilai $p$ value 0.05 sehingga $\mathrm{Ha}$ diterima dan $\mathrm{H} 0$ ditolak artinya bahwa hipotesis diterima atau juga SPIP berpengaruh positif dan signifikan terhadap KLKPD Provinsi Papua.

Hasil penelitian diatas menunjukan bahwa nilai t hitung yang dimiliki SPIP lebih tinggi dibandingkan dengan kompetensi SDM dan penerapan SAKD hal ini disebabkan karena sistem pengendalian internal pemerintah 
sudah berjalan dengan baik. Ini bisa ditunjukan dengan tambah uang (TU) yang dilakukan SKPD harus di SPJ paling lambat 1 bulan, dan apabila melibihi batas waktu yang telah ditentukan maka permintaan dana berikut tidak dapat dilayani sampai dengan SPJ tersebut sudah dilakukan. Dan apabila melewati batas waktu yang telah dilakukan untuk memasukan SPJ di langgar maka akan di berikan sanksi berupa pemanggilan bendahara dan pptk SKPD tersebut untuk memberikan penjelasan terkait keterlambatan SPJ.

Berdasarkan hasil analisis terlihat bahwa Sistem Pengendalian Intern Pemerintah (SPIP) berpengaruh positif dan signifikan terhadap Kualitas Laporan Keuangan Pemerintah Daerah (KLKPD) Provinsi Papua. Hal ini dapat dibuktikan melalui koefisien regresi yang menunjukan jika SPIP meningkat, maka peningkatan tersebut akan diikuti oleh peningkatan KLKPD Provinsi Papua atau dapat dikatakan bahwa KLKPD Provinsi Papua tidak akan meningkat jika tidak terjadi peningkatan pada SPIP.

Temuan ini mendukung pernyataan Weygandt et all., (2005) yang mengungkapkan bahwa: "Jika suatu pengendalian internal telah ditetapkan maka semua operasi, sumber daya fisik, dan data akan dimonitor serta berada dibawah kendali, tujuan akan tercapai, risiko menjadi kecil, dan informasi yang dihasilkan akan lebih berkualitas. Artinya bahwa dengan ditetapkannya pengendalian internal dalam sistem akuntansi, maka sistem akuntansi akan menghasilkan informasi akuntansi yang lebih berkualitas (tepat waktu, relevan, akurat, dan lengkap), dan dapat diaudit (Auditabel).

Memang untuk menghasilkan laporan keuangan pemerintah daerah yang berkualitas tentunya akan tergantung pada seberapa baik penerapan sistim pengendalian internal pemerintah pada daerah tersebut. Mahmudi, (2007) menyatakan bahwa untuk menghasilkan laporan keuangan pemerintah daerah diperlukan proses dan tahap-tahap yang harus dilalui yang diatur dalam sistem akuntansi pemerintah daerah. Sistem akuntansi didalamnya mengatur tentang sistem pengendalian intern (SPI), kualitas 
laporan keuangan sangat dipengaruhi oleh bagus tidaknya sistem pengendalian intern yang dimiliki pemerintah daerah.

Hal yang sama juga disampaikan oleh Amien, (2010) yang menyatakan bahwa efektivitas dan transparansi pengelolaan keuangan daerah dapat terwujud jika setiap entitas pemerintah daerah dapat menciptakan, mengoperasikan serta memelihara sistem pengendalian intern yang memadai secara berkelanjutan, sehingga dapat memberikan keyakinan yang memadai atas terciptanya tujuan instansi, aset negara, dan ketaatan terhadap peraturan perundang-undangan yang berlaku.

Hasil penelitian ini mendukung hasil kajian sebelumnya oleh Roshanti dkk., (2014) yang hasil penelitian menunjukan bahwa sistem pengendalian intern berpengaruh positif dan signifikan terhadap keterandalan pelaporan keuangan pemerintah daerah. Kajian ini juga sejalan dengan kajian Pramudiarta, (2015) yang menunjukan bahwa sistem pengendalian intern pemerintah mempunyai pengaruh positif dan signifikan terhadap nilai informasi pelaporan keuangan entitas akuntansi.

\section{Pengaruh Sistim Akuntansi Keuangan Daerah (SAKD) Terhadap Kualitas Laporan Keuangan Pemerintah Daerah (KLKPD)} Provinsi Papua. Hipotesis ketiga menyatakan bahwa "Sistem Akuntansi Keuangan Daerah (SAKD) berpengaruh terhadap Kualitas Laporan Keuangan Pemerintah Daerah (KLKPD) Provinsi Papua". Berdasarkan hasil analisis diketahui bahwa nilai t hitung koefisien SAKD sebesar 3.444 yang adalah lebih besar dari t tabel sebesar 1.979 (3.444 > 1.979) dengan signifikansi 0.001 yang juga lebih kecil dari nilai $p$ value 0.05 sehingga $\mathrm{Ha}$ diterima dan $\mathrm{HO}$ ditolak artinya bahwa hipotesis diterima atau juga SAKD berpengaruh positif dan signifikan terhadap KLKPD Provinsi Papua.

Hasil analisis menunjukan bahwa SAKD berpengaruh positif dan signifikan terhadap KLKPD Provinsi Papua. Hasil penelitian ini dapat dijustifikasi bahwa penerapan SAKD dilingkungan pemerintah Provinsi Papua selama ini sudah menunjukan perbaikan ke arah yang lebih baik hal ini ditunjukan dengan opini BPK yang diberikan kepada laporan keuangan 
pemerintah Provinsi Papua dengan Wajar Tanpa Pengecualian artinya penerapan system akuntansi keuangan daerah selama ini yang digunakan sudah sesuai dengan prinsip akunatnsi berlaku umum. Dengan demikian, melalui penerapan standar akuntansi pemerintahan yang baik maka pengelolaan keuangan dapat dipertanggungjawabkan sehingga kualitas laporan keuangan akan dapat ditingkatkan.

Hal ini sejalan dengan pendapat Suci Rahmadani, (2015) yang menyatakan bahwa untuk dapat menghasilkan laporan keuangan yang handal, relevan, dapat dipahami dan dipercaya, pemerintah daerah harus memiliki sistem akuntansi yang handal. Sistem akuntansi yang lemah menyebabkan laporan keuangan yang dihasilkan juga kurang handal dan kurang relevan dalam pengambilan keputusan.

Hasil penelitian ini sejalan dengan hasil penelitian Andini dan Yusrawati, (2015) dimana hasil kajiannya menunjukan penerapan sistem akuntansi keuangan daerah berpengaruh terhadap kualitas laporan keuangan daerah. Hasil kajian ini juga mendukung hasil kajian dilakukan oleh Wati dkk., (2014) menumukan bahwa sistem akuntansi keuangan daerah berpengaruh positif dan signifikan terhadap kualitas laporan keuangan daerah.

Pengaruh Kompetensi SDM (KSDM), Sistim Pengendalian Internal Pemerintah (SPIP) dan Sistim Akuntansi Keuangan Daerah (SAKD) Terhadap Kualitas Laporan Keuangan Pemerintah Daerah (KLKPD) Provinsi Papua. Hipotesis keempat atau yang terakhir dalam penelitian ini menyatakan bahwa "Kompetensi sumber daya manusia (KSDM), sistem pengendalian intern pemerintah (SPIP) dan Sistem Akuntansi Keuangan Daerah (SAKD) berpengaruh terhadap kualitas laporan keuangan pemerintah daerah (KLKPD)". Berdasarkan hasil analisis pada Tabel 4.9 terlihat bahwa nilai $F$ hitung adalah sebesar 134.880 yang adalah lebih besar dari besarnya $F$ tabel yang hanya sebesar 3.07 dengan signifikansi 0.000 yang juga lebih kecil dari nilai $p$ value 0.05 sehingga 
$\mathrm{Ha}$ diterima dan $\mathrm{HO}$ ditolak artinya bahwa Kompetensi sumber daya manusia (KSDM), sistem pengendalian intern pemerintah (SPIP) dan Sistem Akuntansi Keuangan Daerah (SAKD) secara simultan berpengaruh secara signifikan dan positif terhadap kualitas laporan keuangan pemerintah daerah (KLKPD) Provinsi Papua.

\section{KESIMPULAN}

Kualitas SDM (KSDM) berpengaruh positif dan signifikan terhadap Kualitas Laporan Keuangan Pemerintah Daerah (KLKPD) Provinsi Papua.

Sistim Pengendalian Internal Pemerintah (SPIP) berpengaruh positif dan signifikan terhadap Kualitas Laporan Keuangan Pemerintah Daerah (KLKPD) Provinsi Papua.

Sistim Akuntansi Pemerintah Daerah (SAKD) berpengaruh positif dan signifikan terhadap Kualitas Laporan Keuangan Pemerintah Daerah (KLKPD) Provinsi Papua.

Kualitas SDM (KSDM), Sistim Pengendalian Intern Pemerintah (SPIP) dan Sistim Akuntansi Keuangan Daerah (SAKD) secara simultan berpengaruh positif dan signifikan terhadap Kualitas Laporan Keuangan Pemerintah Daerah (KLKPD) Provinsi Papua.

\section{DAFTAR PUSTAKA}

Agusty Ferdinand, (2006) Metode Penelitian Manajemen: Pedoman Penelitian Untuk Penulisan Skripsi, Tesis Dan Disertasi IImu Manajemen. Edisi Kedua, Badan Penerbit Universitas Diponegoro, Semarang, Semarang.

Amien, Muhammad Sjukrul. (2010) Mengenal Sistem Pengendalian Intern Pemerintah (SPIP) dan Penerapannya di Provinsi Sumatera Barat, (Online), (http://sumaterabarat.prov.go.id/, diakses 4 Juli 2016).

Arikunto, S. 2003. Prosedur Penelitian Suatu Pendekatan Praktis, Rineka Cipta, Jakarta.

Azhar, La Midjan dan Susanto. 2001. Sistem Informasi Akuntansi I dan II. Edisi ke Sebelas. Lembaga Informatika. Bandung. 
Baridwan Zaki. 1992. Intermediate Accounting. Edisi 7. Yogyakarta: BPFEYogyakarta

Boyatziz, R. E. 1982. Competent Manager. A Model for Effective Performance. John Wiley \& Sons. USA.

Dewi Andini dan Yusrawati, (2015) Pengaruh kompetensi sumber daya manusia dan Penerapan sistem Akuntansi Keuangan Daerah Terhadap Kualitas Laporan Keuangan Daerah Pada Satuan Kerja Perangkat Daerah (SKPD) Kabupaten Empat Lawang Sumatera Selatan, Jurnal Ekonomi, Manajemen dan Akutansi I Vol. 24 No. 1 Juni 2015.

Firdaus. 2016. Pengaruh kualitas sumber daya manusia Pemanfaatan teknologi informasi dan penerapan Kebijakan akuntansi terhadap kualitas Laporan Keuangan Pemerintah Kota Banda Aceh (Studi pada Satuan Kerja Perangkat Daerah di Lingkungan Pemerintah Kota Banda Aceh). http://library.unsyiah.ac.id.

Halim, Abdul. 2005. Akuntansi Sektor Publik. Salemba Empat: Jakarta. Halim, Abdul. 2012. Akuntansi Sektor Publik. Salemba Empat: Jakarta.

Harahap, Sofyan Syafri (2008) Teori Akuntansi. Jakarta: PT, Raja Grafindo Persada

Hutapea, Parulian dan Nurianna Thoha. 2008. Kompetensi Plus. PT. Gramedia Pustaka Utama: Jakarta.

Jensen, M. C nd Meckling, W. H. 1976. Theory of the Firm; Managerial Behavior, Agency Costs and Ownership Structure. JJournal of Financial Economic. Oktober, 1976. Vol.3 No. 4.

Mahmudi (2007). Analisis Laporan Keuangan Daerah: Panduan Bagi Eksekutif, DPRD, dan Masyarakat dalam Pengambilan Keputusan Ekonomi, Sosial, dan Politik. Yogyakarta: UPP STIM YKPN Mahsun,dkk. 2006. Akuntansi Sektor Publik. Yogyakarta.

Pramudiarta, R. (2015). Pengaruh Kompetensi Sumber Daya Manusia, Pemanfaatan Teknologi Informasi, dan Sistem Pengendalian Intern terhadap Nilai Informasi Pelaporan Keuangan Entitas Akuntansi pemerintah daerah (Studi Persepsi Pegawai SKPD di Kabupaten Batang dan Kabupaten Kendal). Skripsi Semarang: Univrsitas Diponegoro 
Priyatno, D., (2012) Belajar Cepat Olah Data Statistik Dengan SPSS, Andi, Yogyakarta.

Sekaran, U. 2006. Research Methoda for Business; A Skill Building Approach. John Wiley and Sons, Inc. Singapore $3^{\text {rd }} \mathrm{E}_{\text {dition. }}$

Suci Rahmadani 2015. Pengaruh Kompetensi Sumber Daya Manusia, Sistem Akuntansi Keuangan Daerah, Pemanfaatan Teknologi Informasi Dan Sistem Pengendalian Intern Terhadap Kualitas Laporan Keuangan Pemerintah Daerah (Studi Pada Satuan Kerja Perangkat Daerah Kabupaten Pasaman Barat). Jurnal Jom FEKON Vol. 2 No. 2 Oktober 2015.

Suci Rahmadani, (2015) Pengaruh Kompetensi Sumber Daya Manusia, Sistem Akuntansi Keuangan Daerah, Pemanfaatan Teknologi Informasi dan Sistem Pengendalian Intern Terhadap Kualitas Laporan Keuangan Pemerintah Daerah (Studi Pada Satuan Kerja Perangkat Daerah Kabupaten Pasaman Barat), Jom Fekon Vol. 2 No. 2 Oktober 2015.

Sudiarianti Ni Made, Ulupui I Gusti Ketut Agung dan Budiasih I. G. A 2015. Pengaruh Kompetensi Sumber Daya Manusia Pada Penerapan Pengendalian Intern Pemerintah dan Standar Akuntansi Pemerintah Serta Implikasinya Pada Kualitas Laporan Keuangan Pemerintah. Simposium Nasional Akuntansi (SNA)18.

Sunyoto, D, (2012) Analisis Validitas \& Asumsi Klasik, Gava Media, Yogyakarta. Suwardjono (2005). Teori Akuntansi: Perekayasaan

Pelaporan Keuangan. Edisi Ketiga. BPFE, Yogyakarta.

Syarifudin Akhmad (2014) Pengaruh Komptensi SDM dan Peran Audit Internal Terhadap Kualitas Laporan Keuangan Pemerintah Daerah Dengan Variabel Intervening Sistem Pengendalian Internal Pemerintah (Studi Empiri Pada Pemkap Kebumen). Jurnal Fokus Bisnis, Volume 14, No 02, bulan Desember 2014

Tanjung Abdul Hafiz 2009. Akuntansi Pemerintah Daerah. Bandung. Alfabeta

Wahyono, Teguh. (2004) Sistem Informasi Akuntansi: Analisis, Desain dan Pemograman Komputer. Yogyakarta: Andi.

Wati Kadek Desiana, Herawati Nyoman Trisna, Sinarwati Ni Kadek (2014) Pengaruh Kompetensi Sdm, Penerapan Sap, Dan Sistem 
Akuntansi Keuangan Daerah Terhadap Kualitas Laporan Keuangan Daerah. e- Journa. Volume 2 No: 1. Tahun 2014.

Weygandt, J.J., et al. (2005). Accounting principles. New York: John Wiley \& Sons.

Woodruffle, C 1990. Human Recource Management. Journal London. Vol. 8:98-100.www.beritapapua.dharapos.com. 2016. Diakses pada hari kamis, 19 Mei. Jam 21.45.

Peraturan : Undang-undang No. 2 tahun 2015 sebagai perubahan Undangundang No. 23 tahun 2014 Pemerintahan Daerah

Undang-Undang No. 33 Tahun 2004 Sebagai Peganti Undang-Undang No. 25 Tahun 1999 Tentang Perimbangan Keuangan Antara Pemerintah Pusat Dan Daerah.

Undang-Undang Republik Indonesia Nomor 58 Tahun 2005, Tentang Keuangan Daerah.

Peraturan Pemerintah No. 60 Tahun 2008 Tentang Sistem Pengendalian Intern Pemerintah

Peraturan Pemerintah No. 71 Tahun 2010 Standar Akuntansi Pemerintahan, Karakteristik Kualitatif Laporan Keuangan Pemerintah.

Peraturan Menteri Dalam Negeri No. 59 Tahun 2007 Tentang Pedoman Pengelolaan Keuangan Daerah.

Peraturan Menteri Dalam Negeri No. 13 Tahun 2006 Tentang Pedoman Pengelolaan Keuangan Daerah 